\title{
Retraction Note: Levels of heavy metals in the straightfin barb Enteromius paludinosus (Peters 1852) from River Malewa, Naivasha, Kenya
}

\author{
Elizabeth A. Ngesa • Elick O. Otachi • Nzula K. Kitaka
}

Published online: 23 April 2020

(C) Springer Nature Switzerland AG 2020

\section{Retraction note to: Environ Monit Assess}

(2019) 191: 292

https://doi.org/10.1007/s10661019-7457-5

The authors have retracted this article [1] because it has been published previously [2] and is therefore a redundant publication. All authors agree with this retraction.

1. Elizabeth A. Ngesa, Elick O. Otachi, Nzula K. Kitaka. Levels of heavy metals in the straightfin barb Enteromius paludinosus (Peters 1852) from
River Malewa, Naivasha, Kenya. Environmental Monitoring and Assessment May 2019, 191:292

2. Elizabeth Adhiambo Ngesa, Elick Onyango Otachi and Nzula Kivuva Kitaka. A Little Fish with a High Heavy Metals Burden: The Case of Straightfin Barb, Enteromius paludinosus (Peters 1852) from River Malewa, Naivasha, Kenya. J Environ Anal Toxicol 2018, Vol 8(4): 583.

Publisher's note Springer Nature remains neutral with regard to jurisdictional claims in published maps and institutional affiliations.

The online version of the original article can be found at https://doi.org/10.1007/s10661-019-7457-5

E. A. Ngesa • E. O. Otachi $(\bowtie) \cdot$ N. K. Kitaka

Department of Biological Sciences, Egerton University,

P.O. Box 536, Egerton, Kenya

e-mail: elickotachi@gmail.com 